\title{
A first evaluation on the use of Ardea albus feathers as bioindicators of mercury burden in Amazonian ecosystems
}

\author{
Andreza lourdes GOMES ${ }^{1}$, José Luiz Fernandes VIEIRA², Maria da Conceição Nascimento PINHEIRO³, \\ Maria Luiza Videira MARCELIANO ${ }^{4}$
}

\section{ABSTRACT}

We evaluated in this study the total mercury concentration in feathers of Ardea albus collected in a colony located in the city of Belem-PA, Brazil in a prospective trial for its use as bioindicators of mercury burden in Amazonia ecosystems. An Atomic absorption spectrophotometry with gold amalgamation was used for the metal determination. The total mercury average concentration in body feathers was $2.2 \pm 1.5 \mu \mathrm{g} \cdot \mathrm{g}^{-1}$ and $1.3 \pm 0.9 \mu \mathrm{g} \cdot \mathrm{g}^{-1}$ in wing feathers. No correlation was observed between total mercury concentration and the length of body or wing feathers. Total mercury concentration was above $5 \mu \mathrm{g} \cdot \mathrm{g}^{-1} \mathrm{dry}$ weight in only one body feather sample.

KEYWORDS: Mercury, Ardea albus, Birds, Feathers, Environmental.

\section{Avaliação preliminar do uso de penas de Ardea albus como bioindicadoras de mercúrio em ecossistemas amazônicos}

\section{RESUMO}

O objetivo deste estudo foi avaliar as concentraçóes de mercúrio total em penas de Ardea albus coletadas em uma assembléia de aves localizada nas imediaçôes da cidade de Belém, Pará, com vistas a investigar a possibilidade do uso desta espécie nos estudos de biomonitoramento deste metal. Para determinação de mercúrio total foi utilizada a espectrofotometria de absorção atômica com amalgamação. A concentração média de mercúrio total nas penas do corpo foi $2,2 \pm 1,5 \mu \mathrm{g} \cdot \mathrm{g}^{-1} \mathrm{e}$ nas penas das asas foi $1.3 \pm 0.9 \mu \mathrm{g} / \mathrm{g}^{-1}$. Não foi observada correlação entre a concentração de mercúrio total e o comprimento das penas do corpo e da asa. Foi observado teor de mercúrio total superior a $5 \mu \mathrm{g} \cdot \mathrm{g}^{-1} \mathrm{em}$ apenas uma amostra de pena do corpo.

PalaVRaS-ChaVE: Mercúrio, Ardea albus, Aves, Penas, Biomonitoramento.

\footnotetext{
${ }_{1}^{1}$ Museu Paraense Emílio Goeldi. Av. Perimetral, 1901 - Terra Firme CEP: 66077-830 - Belém - PA - Brasil. Tel/Fax: (55) 91-32740423. E-mail: algomes@museu-goeldi.br

2 Universidade Federal do Pará. E-mail: jvieira@ufpa.br

${ }^{3}$ Universidade Federal do Pará. E-mail: nconci@ufpa.br

${ }^{4}$ Museu Paraense Emílio Goeldi. E-mail: mlvideira@museu-goeldi.br
} 


\section{INTRODUCTION}

Feathers have been widely used as an indicator of bird's exposure to mercury compounds and other heavy metals and are a relevant tissue for evaluating chronic body burdens (Appelquist et al., 1984). The non-invasive sampling of feathers allows them to be used for the exposure evaluation of threatened or endangered species, permits the sampling of large number of birds, and enables repeated sampling from the same individual over many years (Burger \& Gochfeld, 1997, Kojadinovic et al., 2007). They are the major depuration route for methyl mercury and a high degree of correlation has been show between mercury accumulation in feathers and others tissues. Previous studies showed that mercury in the diet is incorporated in feathers in a dose-dependent manner and methyl mercury corresponds to about $83-90 \%$ of total mercury in feathers. (Spalding et al., 2000; Thompson \& Furness, 1989). The piscivorous birds are at particularly high risk to mercury toxicity because many species are at high trophic levels, long lived, and are vulnerable to health impacts from exposure to elevated levels of this metal (Burger \& Gochfeld, 1997). The objective of this study was to determine total mercury in feathers of Ardea albus a resident member of the predatory waterbirds community of Amazonia, in a first attempt to investigate its use as biomonitoring tool for exposure assessment.

\section{MATERIAL AND METHODS}

Twelve specimens adults of A.albus were sampled in the period from January to July 2006, in a colony located at Batista Campos square in the city of Belém, Pará ( $1^{\circ} 27^{\prime} 36^{\prime \prime}$ S, 48 $29^{\prime} 23^{\prime \prime}$ W), which represented $10 \%$ of Ardea albus local community. This square is located in the center of the city and no sources of mercury compounds were identified. Between 10 and 15 feathers were collected from each single individual from body and wings. The feathers from each specimen were separated in three samples performing a total of 36 samples from body and 36 samples from wings feathers, and placed into individually labeled plastic bags and stored at $-4^{\circ} \mathrm{C}$.

For total mercury determination, two feathers from each sample were cut in small pieces and washed in ultrasonic bath for 5 minutes as follows: ultrapure water $(<18 \mathrm{~m} \Omega)$, acetone and ultrapure water $(<18 \mathrm{~m} \Omega)$. They were then oven-dried at $40^{\circ} \mathrm{C}$ for $24 \mathrm{~h}$. The dried samples were weighed in sample boats and placed in a dessicator. The total mercury content was determined in the feather samples using previously described technique (Pinheiro et al., 2007). Briefly, the boats containing the samples are introduced in the equipment and heated in oven at $800^{\circ} \mathrm{C}$. The mercury vapor formed is collected in two successive gold traps and determination is performed by atomic absorption spectrophotometry (Nippon Instruments Corporation). The results were expressed in $\mu \mathrm{g} \cdot \mathrm{g}^{-1}$ on a dryweight basis. A blank sample without feathers was analyzed after the samples of each specimen.

The detection limit was considered as three times the value of standard deviation of the blank at least 8 blanks and was equal to $3 \mathrm{ng} \cdot \mathrm{g}^{-1}$. The accuracy and precision of the procedure used were tested by submitting to the same treatment replicates of a dog fish muscle (DORM- 2) certified reference material (National Research Council, Canada); measured values were always within $\pm 10 \%$ of the reference value $\left(4.64 \mu \mathrm{g} \cdot \mathrm{g}^{-1}\right)$. Repeatability was estimated by the coefficient of variation was always lower than $15 \%$. Correlation among total mercury average concentration and length average of each specimen was determined using Pearson coefficient $(\mathrm{r}), t$ - test was used to compare difference between total mercury average concentration in body and wing feathers of each specimen and the variability of total mercury concentration between and within specimens was estimated by the coefficient of variation. Statistical significance was accepted at $P<0,05$. Statistical analyses were performed using the statistical software program Sigmastat ${ }^{\mathrm{TM}}$ (Jandel Corporation, San Rafael, CA).

Table 1 - Length and total mercury concentration in feathers of Ardea albus , collected in Belém-Brazil, in 2006.

\begin{tabular}{lccccc}
\hline Feathers & $\mathrm{n}^{*}$ & $\begin{array}{c}\text { Feathers Length }(\mathrm{cm}) \\
\mathrm{X}( \pm) \text { s.d. }\end{array}$ & $\mathrm{THg}\left(\mu \mathrm{g} / \mathrm{g}^{-1}\right) \mathrm{X}( \pm)$ s.d. & $\begin{array}{c}\mathrm{THg}\left(\mu \mathrm{g} / \mathrm{g}^{-1}\right) \\
\text { Range }\end{array}$ & Critical $p$ value \\
\hline Body & 12 & $13.7 \pm 6.05$ & $2.2 \pm 1.5$ & $0.76-6.02$ & 0,3524 \\
Wings & 12 & $17.5 \pm 4.5$ & $1.3 \pm 0.9$ & $0.6-3.8$ & 0,2321 \\
\hline
\end{tabular}

* each specimen contribute with three samples

$n=$ number of specimens

$\mathrm{THg}=$ Total mercury concentration.

$X( \pm)$ s.d. = mean value and standard deviation

$r=$ Pearson coefficient 


\section{RESULTS AND DISCUSSION}

The results presented in Table 1 agrees with previous investigations with Ardeid species, as in Florida, US where the concentration of total mercury in feathers from A. albus nestling, age 11-31 days, ranged from 1.4 to $8.6 \mu \mathrm{g} . \mathrm{g}^{-1} \mathrm{dry}$ weight (Rumbold et al.,2001), and in the vicinity of Hong Kong, China with Egretta garzetta and Nychicorax nychicorax, where the concentration of total mercury in feathers ranged from 0.0 to $7.1 \mu \mathrm{g} . \mathrm{g}^{-1}$ dry weight and 0.2 to $3.8 \mu \mathrm{g} . \mathrm{g}^{-1}$ dry weight, respectively (Connell et al., 2002).

Was observed significant correlation in total mercury concentration between body and wings feathers (critical $\mathrm{p}$-value $=0.044)$. Furness et al. $(1986)$ also reported that the body feathers provided the most representative sample for estimating whole-bird mercury content. The coefficients of variation of total mercury concentration in feathers samples of the same specimen were $8.5 \%$ and $7.8 \%$, and between different specimens were $68.1 \%$ and $64.1 \%$, for body and wings feathers, respectively.

There are few studies that examine the levels of mercury in feathers that are associated with behavioral, growth, or reproductive abnormalities. The presence of high level of mercury in Ardeid species has been associated with adverse effect on the breeding success (Conell et al., 2002; Lucca Aboot et al., 2001). Eisler (1987) evaluated the effects of mercury in feathers associated with breeding success for many bird species and suggested that the threshold for adverse effects associated with mercury in feathers is 3 to $5 \mu \mathrm{g} \cdot \mathrm{g}^{-1} \mathrm{dry}$ weight. In this study, only a sample of the body feathers and wing feathers had total concentration of mercury that exceeds this threshold.

No correlation was observed between total mercury concentration and the length of body (critical p-value = 0,3524 ) and wings feathers (critical $p$-value $=0,2321$ ). This may be explained by the fact that feather mercury levels reflect the cumulative amount of mercury stored in body tissues rather than the immediate intake. Also, A. albus generally forage on lakes and commonly use multiple water bodies within their breeding territory, which can result in an irregular exposure to mercury compounds (Spalding et al., 2000). This can be considered the limitations for use of $A$. albus feathers as bioindicators of mercury burdens.

The mercury values found in the feathers of Ardea albus recommend further studies on its use as bioindicators of mercury exposure in Amazonia. However, it is also necessary to consider the background values of mercury in different environmental compartments, the path of mercury in their food chains and the timing of feathers growth in relation to mercury exposure.

\section{LITERATURE CITED}

Appelquist, H.; Asbirk, S.; Drabaek, I. 1984. Mercury monitoring: Mercury stability in bird feathers. Marine Pollution Bulletin, $15: 22-24$.

Burger, J.; Gochfeld, M. 1997. Risk, Mercury Levels, and Birds: Relating Adverse Laboratory Effects to Field Biomonitoring. Environmental Research, 75:160-172.

Connell, D.W.; Wong, B.S.F.; Lam, P.K.S.; Poon, K.F.; Lam, M.H.V.; Wu, R.S.S.; Richardson, B.J; Yen, Y.F. 2002. Risk to breeding success of Ardeids by contaminants in Hong Kong: Evidence from trace metals in feathers. Ecotoxicology. 11: 49-59.

Eisler, R. 1987. Mercury hazards to fish, wildlife, and invertebrates: A synoptic review. U.S. Fish and Wildlife Service. Biological Report, 85(10):1-10.

Furness, R.W.; Muirhead, S.J.; Woodburn, M. 1986. Using bird feathers to measure mercury in the environment: Relationships between mercury content and moult. Marine Pollution Bulletin , 17:27-30.

Kojadinovic, S.; Bustamante, P.; Churlaud, C.; Cosson, R.P.; Le Corre, M. 2007. Mercury in seabird feathers: Insight on dietary habits and evidence for exposure levels in the western Indian Ocean. The Science of the Total Environment 384: 194-204.

Luca-Abbot, S.B.; Wong, B.S.Y.; Peakall, D.B.; Lam, P.K.S.; Young, L.; Lam, M.H.W.; Richardson, B.J. 2001. Review of effects of water pollution on the breeding success of waterbirds, with particular reference to ardeids in Hong Kong. Ecotoxicology, 10:327-349.

Nippon Instruments Corporation. 2003 Instruction manual for mercury SP-3D (mercury analyzer), Manual n 600-1003-00, 27p. Osaka, Japan.

Pinheiro, M.C.N.; Crespo-Lopz, M.E.; Vieira, J.L.F.; Oikawa, T.; Guimaraes, G.A.; Araujo, C.C.; Amoras, W.W.; Ribeiro, D.R.; Herculano, A.M.; Nascimento, J.L.M.; Silveira, L.C.L. 2007. Mercury pollution and childhood in Amazon riverside villages. Environment International, 33:56-61.

Rumbold, D.G.; Niemczyk, S.L.; Fink, L.E.; Chandrasekhar, T.; Haranson, B.; Laine, K.A. 2001. Mercury in Eggs and Feathers of Great Egrets (Ardea albus) from the Florida Everglades. Archives of Environmental Contamination and Toxicology. 41, 501-507.

Spalding, M.G.; Frederick, P.C.; McGill, H.C.; Bouton, S.N.; McDowell, L.R. 2000. Methyl mercury accumulation in tissues and its effects on growth and appetite in captive great. Journal Wildlife Diseases, 36:411-422.

Thompson, D.R; Furness, R.W.1989. Comparison of total and organic mercury levels in seabird feathers. Marine Pollution Bulletin, 20:577-79.

Recebido em 04/11/2008

Aceito em 13/02/2009 
